\title{
Anaerobic co-digestion of sewage sludge and molasses
}

\author{
Katarzyna Kalemba ${ }^{1, *}$, and Krzysztof Barbusiński ${ }^{1}$ \\ ${ }^{1}$ Silesian University of Technology, Faculty of Energy and Environmental Engineering, Poland
}

\begin{abstract}
The efficiency of simultaneous digestion of sewage sludge and by-product of refining sugar beets (molasses) was investigated. The study was conducted for 28 days under mesophilic conditions. $0.5 \%, 1 \%, 1.5 \%$, $2 \%$ and $3 \%(\mathrm{~m} / \mathrm{m})$ of molasses was added to the mixture of sludge. The result of the study showed that addition of molasses had positive effect the biogas production. The biggest biogas yield was achieved in sample with $0.5 \%$ of molasses $(95.69 \mathrm{~mL} / \mathrm{g}$ VS). In this sample biogas production increased by $21 \%$ in comparison with reference sample (without molasses). The biggest methane content $(73 \%)$ was also observed in the sample with $0.5 \%$ of molasses. For comparison in reference sample was produced biogas with $70 \%$ content of methane. The dose over $0.5 \%$ of molasses caused inhibition of fermentation process. The minimal degree $(38 \%)$ of degradation of organic matter was achieved in reference sample $(38.53 \%)$ and in sample with $0.5 \%$ of molasses $(39.71 \%)$ but in other samples was in the range of $35.61-36.76 \%$ (from 3\% to $1 \%$, respectively). Digestion process have adverse effect on dewatering properties of sludge. Before co-digestion capillary suction time was from $31 \mathrm{~s}$ to $55 \mathrm{~s}$, and after process increased from $36 \mathrm{~s}$ to $556 \mathrm{~s}$ (from $0 \%$ to $3 \%$ of molasses, respectively).
\end{abstract}

\section{Introduction}

Anaerobic co-digestion is process of simultaneous digestion two or more substrates come from different source, occur in four phases: hydrolysis, acidogenesis, acetategenesis and methanogenesis. The addition of co-substrate is the option to overcome the drawback of mono-digestion e.g. low organic load of sewage sludge, low organic load and high nitrogen concentration of animal manures, improper material and relatively high concentration of heavy metals in organic fraction of municipal solid waste, lack of nitrogen in crops and agro-industrial wastes and high concentration of nitrogen and long chain fatty acids in slaughterhouse wastes. Co-digestion is more economical process than mono-digestion because enhance the methane production. Moreover, co-digestion process lead in one fermentation tank could produce more methane than fermentation process conduct in two digesters. Another benefits of co-digestion are acceleration the digestion process and bringing higher degradation rates $[1,2]$.

\footnotetext{
* Corresponding author: katarzyna.kalemba@polsl.pl
} 
In the world in 2015/2016 year (from October to September) was produced 165,8 million $t$ of sugar from sugar beet [3]. From each kilogram of sugar beet is obtained $75 \%$ water and $25 \%$ of dry substance. From dry substance is formed a product and the rest is turned into a by-product. The main by-product of the sugar factory are: pulp, carbonation-lime residue and molasses. First of all the sugar beets are washed, sliced and soaked in hot water to begin the process that separates sugar from the rest of the plant. As a result of extraction is made the hot sugary liquid and pulp. To hot sugary liquid is added lime and $\mathrm{CO}_{2}$ to purification. The mixture is filtered so the runny syrup is made. As a by-product is obtained carbonation-lime residue. The runny syrup is evaporated and crystallization. At the end, hot water is sprayed over the light brown crystals to remove the remaining molasses, leaving pure naturally white sugar crystals. The sugar crystals are then dried [4]. Beet molasses contain 48\% sugar (namely sucrose and invert sugar) and $79.5 \%$ dry substances. It is the most valuable by-product of the sugar factory because is used as a carbon source in the yeast fermentation and ethanol fermentation, as animal feed, as fertilizer and for biogas production $[5,6]$. There are several reports of co-digestion molasses with other substrates [7-9] but is no report about co-digestion of molasses with sewage sludge.

The main objective of this paper was to examine the process of anaerobic co-digestion of sewage sludge and molasses. The attention was focused on biogas production, the composition of biogas, the VFA/A ratio and dewatering properties. The efficiency of the process in terms of molasses ratio was also examined.

\section{Methods}

\section{Characteristics of the substrates}

Mixed thickened surplus activated sludge from municipal sewage treatment plant and byproduct of refining sugar beets (molasses) was used in this investigation. Surplus activated sludge was obtained from sludge treatment system. Then, surplus activated sludge was inoculated by fermenting sludge from the digester. Molasses was obtain from yeast plant. The sample of molasses were dissolved by deionized water because of thick texture. The characteristics of supernatant liquor and molasses are shown in table 1 . The sludge mixture (surplus activated sludge with $50 \mathrm{~g}$ of fermenting sludge) was mixed with 2, 4, 6, 8 and $12 \mathrm{~g}$ of molasses what corresponds to $0.5 \%, 1.0 \%, 1.5 \%, 2.0 \%$ and $3.0 \%$ ratio of molasses in the samples. The sludge without co-substrate was a reference. The weight of each sample was $400 \mathrm{~g}$.

Table 1. Characteristics of supernatant liquor and molasses.

\begin{tabular}{|c|c|c|c|}
\hline Parameter & Unit & Supernatant liquor & Molasses \\
\hline $\mathrm{pH}$ & - & 7.1 & 8.5 \\
\hline $\mathrm{COD}$ & $\mathrm{mgO}_{2} / \mathrm{L}$ & 603.2 & 13300.0 \\
\hline Volatile fatty acid (VFA) & $\mathrm{mg} \mathrm{CH}_{3} \mathrm{COOH} / \mathrm{L}$ & $<28$ & 545 \\
\hline Alkalinity (A) & $\mathrm{mg} \mathrm{CaCO}_{3} / \mathrm{L}$ & 475 & 935 \\
\hline
\end{tabular}

\section{Laboratory installation}

The sludge fermentation study was conducted for 28 days under static conditions, in 12 airtight glass flask (reactors) with a capacity of $500 \mathrm{~mL}$ each, at the mesophilic conditions $\left(37^{\circ} \mathrm{C}\right)$. To keep temperature constant, the flasks were placed in a water bath. The installation was equipped with a device to collect biogas. The flasks were not mixed, therefore the mixture was stirred 2 times a day without disconnecting devices to receive biogas. 
Analysis

Before and after the experiment the following analyses were carried out:

- total solids (TS) and volatile solids (VS) according to PN-EN 12879:2004 [10] and PN-EN 12880:2004 [11];

- $\mathrm{pH}$ according to PN-EN 12176:2004 [12];

- total alkalinity according to PN-91/C-04540/05 [13];

- volatile fatty acid made based on cuvette test Hach Lange;

- capillary suction time according to PN-EN 14701-1 [14].

The volume of biogas was recorded every day and the composition of the produced biogas was measured by Multitec 540 analyser (Sewerin).

\section{Results and discussion}

\section{Efficiency of co-digestion}

The results of the study showed that addition of molasses have positive influence on the cumulative biogas production. Fig. 1 shows the biogas yields in term of VS of the tested ratio of molasses. After 28 days of co-digestion the biggest biogas yield was reached in a sample with $0.5 \%$ of molasses $(95.69 \mathrm{~mL} / \mathrm{g} \mathrm{VS})$. In this sample biogas yield increased by $21 \%$ in comparison to the reference sample $(79.17 \mathrm{~mL} / \mathrm{g}$ VS). Additionally, in sample with $0.5 \%$ of molasses continued increase of biogas production was observed. However, enhancement the content of molasses over $0.5 \%$ resulted the inhibition of biogas production due to organic overloading but in sample with $1 \%$ of molasses the biogas production $(75.55 \mathrm{~mL} / \mathrm{g} \mathrm{VS}$ ) was similar to the reference sample. The lowest biogas yield was noticed in the sample when molasses fraction was $3 \%(27.20 \mathrm{~mL} / \mathrm{g} \mathrm{VS})$.

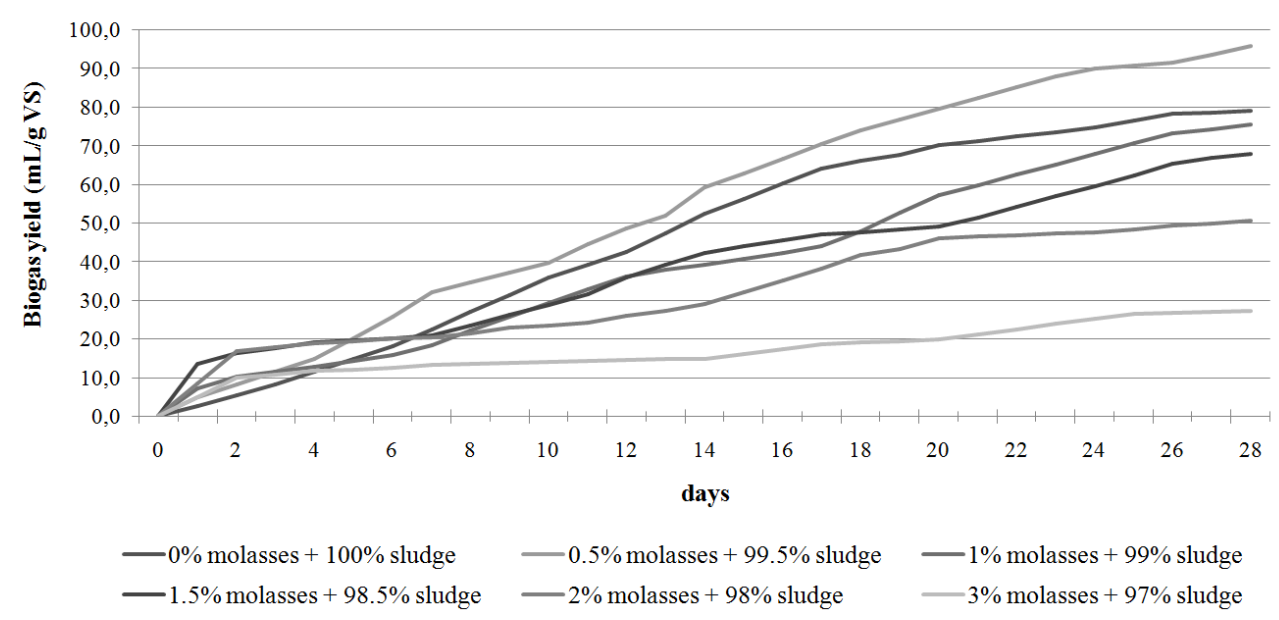

Fig. 1. Biogas yield during anaerobic digestion.

The addition of molasses had impact in the composition of biogas. Biogas produced in the anaerobic digestion of sewage sludge usually contains about $60 \%$ methane [15]. The results of this study confirm that addition of substrates had a positive influence on methane content in biogas (Fig. 2). In the reference sample biogas contained up to $70 \%$ of methane. The biggest content of methane in biogas (up to $73 \%$ ) was detected in the sample with $0.5 \%$ of molasses. After 14 day of fermentation process in reference sample and in the sample with $0.5 \%$ of molasses the same methane content $(65 \%)$ was reached. This situation continued up to 22 day of fermentation when methane content in both of sample reached $70 \%$. Later methane content in reference sample remained on the constant level. However, 
in sample with $0.5 \%$ of molasses the ratio of methane enhanced to $73 \%$. It could be explained by a long time adaptation of microorganisms to molasses, probably due to the low susceptibility of molasses to biological degradation under anaerobic conditions. The lowest methane content (28\%) was observed in the sample with $3 \%$ of molasses. As expected, this result was in agreement with the amount of biogas yield.

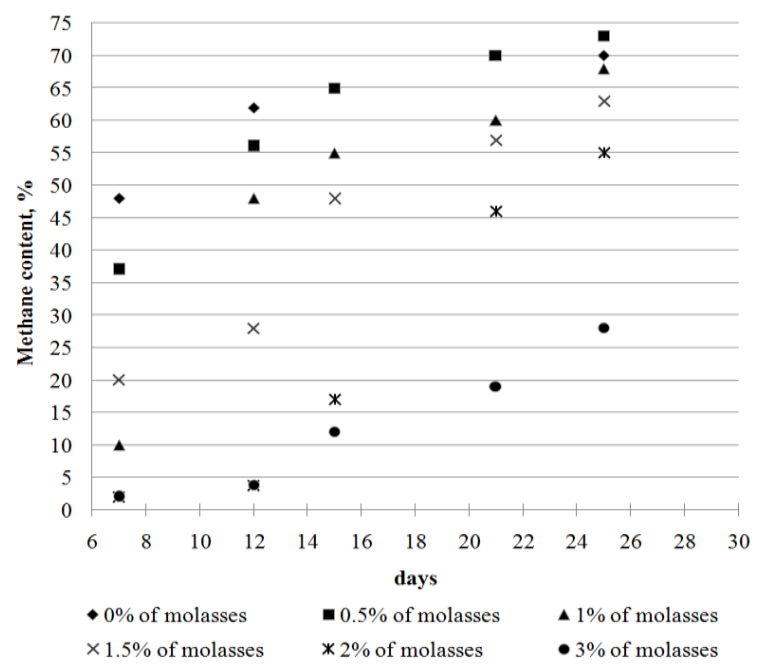

Fig. 2. The methane content in biogas during anaerobic digestion.

The degree of degradation of organic matter was calculated based on the changes in concentration of volatile solids before and after anaerobic stabilization (Tab. 2). The biggest degree of degradation (39.71\%) was observed in sample with the biggest production of biogas $(0.5 \%$ of molasses). According to Environmental Protection Agency the minimal reduction of volatile solids should be $38 \%$ [16]. In reference sample and in the sample with $0.5 \%$ of molasses the minimal degree of anaerobic stabilization was achieved. In the other sample sufficient degradation of organic matter was not reached but results $(35.80 \%$ $36.76 \%$ ) were very close to minimal degree of degradation of organic matter.

Table 2. The degree of degradation of organic matter.

\begin{tabular}{|c|c|c|c|}
\hline \multirow{2}{*}{$\begin{array}{l}\text { The amount of } \\
\text { molasses, } \%\end{array}$} & \multicolumn{2}{|c|}{ Volatile solids, g/L } & \multirow{2}{*}{$\begin{array}{c}\text { The degree of anaerobic } \\
\text { stabilization, } \%\end{array}$} \\
\hline & Before co-digestion & After co-digestion & \\
\hline 0 & 31.66 & 19.46 & 38.53 \\
\hline 0.5 & 42.66 & 25.72 & 39.71 \\
\hline 1.0 & 43.88 & 27.75 & 36.76 \\
\hline 1.5 & 44.17 & 28.40 & 35.71 \\
\hline 2.0 & 47.71 & 30.72 & 35.61 \\
\hline 3.0 & 50.36 & 32.33 & 35.80 \\
\hline
\end{tabular}

\section{The change of $V F A / A$ ratio}

Concentration of VFA has a significant influence on the efficiency of anaerobic digestion. VFA is an important mid-product in the formation of methane. The result of study showed that the amount of the volatile fatty acids had effects the anaerobic digestion process. The higher ratio of molasses the higher concentration of VFA (Tab. 3). After co-digestion process in sample over $0.5 \%$ of molasses accumulation of VFA was observed. As a result, the methanogenesis was inhibited and $\mathrm{pH}$ was decline. Therefore, decrease of biogas production in sample over $0.5 \%$ was detected. 
Examining concentration of VFA and $\mathrm{A}$ is recommended strategy to control codigestion process. The VFA/A ratio up to 0.3 provides a balance between acidogenic and methane bacteria [17]. The results of the study confirmed this literature report. In the samples with $1 \%, 1.5 \%, 2 \%$ and $3 \%$ of molasses where ratio was over 0.3 the biogas yield, the methane content in biogas and the reduction of organic matter was lower than in reference sample.

Table 3. The physical-chemical analysis of supernatant liquid.

\begin{tabular}{|c|c|c|c|c|c|c|c|}
\hline \multicolumn{2}{|c|}{ The amount of molasses, $\%$} & $\mathbf{0}$ & $\mathbf{0 . 5}$ & $\mathbf{1 . 0}$ & $\mathbf{1 . 5}$ & $\mathbf{2 . 0}$ & $\mathbf{3 . 0}$ \\
\hline \multirow{2}{*}{$\mathrm{pH}$} & Before co-digestion & 7.1 & 7.1 & 7.1 & 7.3 & 7.2 & 7.3 \\
\cline { 2 - 8 } & After co-digestion & 7.8 & 7.9 & 7.5 & 7.4 & 7.0 & 5.7 \\
\hline \multirow{2}{*}{$\begin{array}{c}\mathrm{A}, \\
\mathrm{m} \mathrm{CaCO}_{3} / \mathrm{L}\end{array}$} & Before co-digestion & 475 & 400 & 375 & 450 & 375 & 475 \\
\cline { 2 - 8 } & After co-digestion & 2690 & 3019 & 2805 & 3063 & 2755 & 2465 \\
\hline $\begin{array}{c}\mathrm{VFA}, \\
\mathrm{mg} \mathrm{CH}_{3} \mathrm{COOH} / \mathrm{L}\end{array}$ & Before co-digestion & 28 & 66 & 117 & 166 & 210 & 269 \\
\cline { 2 - 8 } & After co-digestion & 73 & 163 & 1106 & 1982 & 2743 & 3521 \\
\hline \multirow{2}{V}{$\mathrm{VFA} / \mathrm{A}$} & Before co-digestion & 0.06 & 0.17 & 0.31 & 0.37 & 0.56 & 0.57 \\
\cline { 2 - 8 } & After co-digestion & 0.03 & 0.05 & 0.39 & 0.65 & 1.00 & 1.43 \\
\hline
\end{tabular}

\section{Dewatering properties}

The addition of molasses impacted dewatering properties of sludge. The capillary suction time (CST) test is widely used method to determine the filterability and the easiness of removing moisture from slurry and sludge [18]. Generally, digestion process have adverse effect on dewatering properties of sludge. The capillary suction time enhanced after co-digestion process in each sample (Fig. 3). In the reference sample CST increased from $31 \mathrm{~s}$ to $36 \mathrm{~s}$ but in other samples expansion was more significantly. After co-digestion, with increasing content of molasses, CST increased from $111 \mathrm{~s}$ to $556 \mathrm{~s}$ (from $0.5 \%$ to $3 \%$ of molasses, respectively).

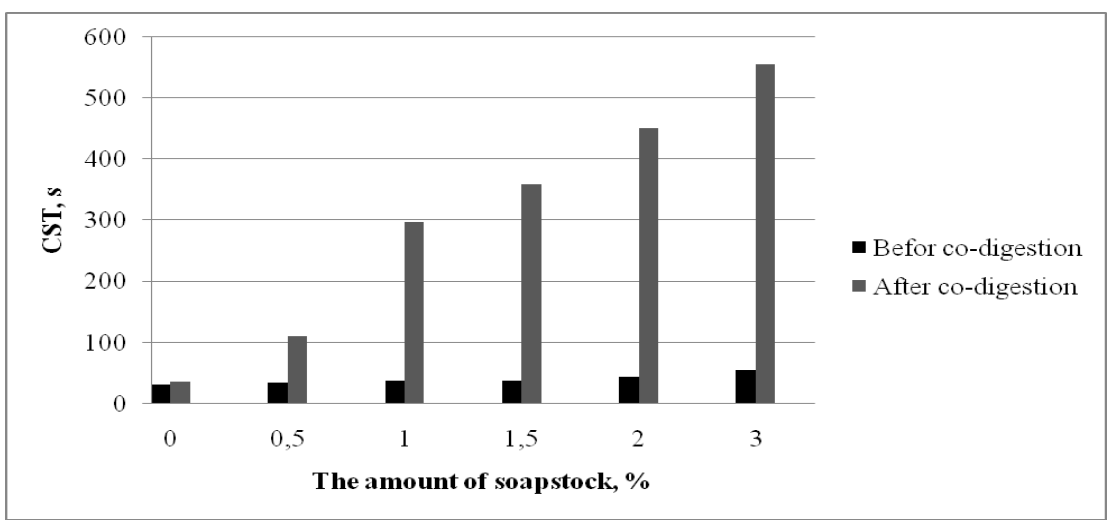

Fig. 3. Changes of CST value for different contents of molasses.

\section{Comparison of biogas production for a different co-substrates at their optimum content}

The authors of this publication also done research process of co-digestion with other organic co-substrates. In this investigations were used: waste meat, soapstock, by-product after biodiesel production and waste from fat separator. These compounds have not yet been widely investigated as substrates for fermentation with sewage sludge. However, the results of such applications can be found in a few publications [19-22]. Table 4 shows the 
results of the maximum biogas production and methane content in biogas under optimum conditions of the fermentation process for different organic co-substrates. Methane content in biogas was the biggest using waste meat (76\%). The similar methane content $(72-73 \%)$ was reached in soapstock, by-product after biodiesel production and molasses investigation. The lowest methane content in biogas was achieved in waste from fat separator investigation. The maximum biogas production using molasses was $95.69 \mathrm{~mL} / \mathrm{g} \mathrm{VS}$ and was only slightly higher than in case of application of waste from fat separator. For other substrates the biogas production was higher. However, compared to other substrates, the maximum biogas production and a relatively high methane content using molasses was obtained with the smallest content of this substrate $(0.5 \%)$ in a mixture with sewage sludge. Therefore, molasses appears to be a substrate, which should be considered for use in wastewater treatment plants in the process of co-digestion, especially in the case when the digesters have a small supply of additional capacity.

Table 4. The maximum biogas production and methane content in biogas for different organic cosubstrates.

\begin{tabular}{|c|c|c|c|}
\hline Organic co-substrates & $\begin{array}{c}\text { Maximum biogas } \\
\text { production } \\
\text { (mL/g VS) }\end{array}$ & $\begin{array}{c}\text { Methane content } \\
\text { in biogas } \\
\mathbf{( \% )}\end{array}$ & $\begin{array}{c}\text { Content of substrate } \\
\text { in the sample } \\
(\mathbf{\%})\end{array}$ \\
\hline Waste meat & 170.30 & 76 & 3 \\
\hline Soapstock & 117.17 & 73 & 10 \\
\hline $\begin{array}{c}\text { By-products after } \\
\text { biodiesel production }\end{array}$ & 99.91 & 72 & 10 \\
\hline Molasses & 95.69 & 73 & 0.5 \\
\hline Waste from fat separator & 88.68 & 70 & 3 \\
\hline
\end{tabular}

\section{Conclusion}

Addition of molasses had positive influence on biogas production. The biggest biogas yield was reached in sample with $0.5 \%$ of molasses and was $21 \%$ higher than in reference sample. Co-digestion process of sludge and molasses influenced on biogas composition. In sample with $0.5 \%$ of molasses methane content increased to $73 \%$. The higher dose of molasses than $0.5 \%$ caused inhibition of the digestion process, thus $0.5 \%$ of molasses is optimum dose. According to the EPA regulations, the degrees of degradation of organic matter obtained in reference sample and in sample with $0.5 \%$ of molasses were significant, because it exceeded $38 \%$. In the other samples sufficient degradation of organic matter was not reached, but obtained results $(35.61 \%-36.76 \%)$ were very close to $38 \%$. The result of VFA/A ratio indicated that $0.5 \%$ of molasses is the optimum dose because higher content caused inhibition of co-digestion. Generally, digestion process have adverse effect on dewatering properties. After co-digestion, with increasing content of molasses, CST increased from $36 \mathrm{~s}$ to $556 \mathrm{~s}$ (from $0 \%$ to $3.0 \%$ of molasses, respectively). This information should be taken into account in the design of sludge dewatering process.

Based on the obtained results it can be stated that molasses is a substrate which can be used in wastewater treatment plants in the process of co-digestion, especially in the case when the digesters have a small supply of additional capacity.

\section{References}

1. J. Mata-Alvarez, J. Dosta, M.S. Romero-Güiza, X. Fonoll, M. Peces, S. Astals, Renew. Sust. Energ. Rev. 36, 412-427 (2014) 
2. P. Aichinger, T. Wadhawan, M. Kuprian, M. Higgins, Ch. Ebner, Ch. Fimml, S. Murthy, B. Wett, Water Res. 87, 416-423 (2015)

3. Sugar production, United State Department of Agriculture (USDA), November 2016

4. M. Asadi, Beet-Sugar Handbook (John Wiley \& Sons, Inc. 2007)

5. Ch. Fang, K. Boe, I. Angelidaki, Bioresour. Technol. 102, 1005-1011 (2011)

6. X. Wu, H. Lin, J. Zhu, Bioresour. Technol. 136, 351-359 (2013)

7. I. Rodriguez-Verde, L. Regueiro, M. Carballa, A. Hospido, J.M. Lema, Sci. Total Environ. 497-498, 475-483 (2014)

8. P. Kongjan, S. O-Thong, I. Angelidaki, Eng. Life Sci. 13, 2, 118-125 (2013)

9. Ch. Fang, K. Boe, I. Angelidaki, Bioresour. Technol. 102, 1005-1011 (2011)

10. PN-EN 12879:2004 Charakterystyka osadów ściekowych. Oznaczanie strat przy prażeniu suchej masy osadu (Characteristics of sludge. Determination of the loss of ignition of dry mass).

11. PN-EN 12880:2004 Charakterystyka osadów ściekowych. Oznaczanie suchej pozostałości i zawartości wody (Characteristics of sludge. Determination of dry residue and water content).

12. PN-EN 12176:2004 Charakterystyka osadów ściekowych. Oznaczanie wartości pH. (Characteristics of sludge. Determination of $\mathrm{pH}$ value).

13. PN-91/C-04540/05 Badania pH, kwasowości i zasadowości. Oznaczanie pH, kwasowości i zasadowości mineralnej i ogólnej w osadach ścieków miejskich. (Tests for $\mathrm{pH}$, acidity and alkalinity. Determination of $\mathrm{pH}$, mineral and total acidity and alkalinity in sludge of urban waste waters).

14. PN-EN 14701-1 Charakterystyka osadów ściekowych. Właściwości filtracyjne. Część 1: Czas ssania kapilarnego (CST). (Characteristics of sludge. Filtration properties. Capillary suction time; CST).

15. R. Wickham, B. Galway, H. Bustamante, L.D. Nghiem, Int. Biodeter. Biodegr. 113, 3-8 (2016)

16. U.S. EPA, Pathogen and vector attraction reduction requirements, EPA/832/R-93/003, Washington, September, 1994.

17. J. Bień, K. Wystalska, Osady ściekowe. Teoria i praktyka (Wydawnictwo Politechniki Częstochowskiej, 2011)

18. O. Sawalha, M. Scholz, Environ. Technol. 28, 12, 1377-1386 (2007)

19. K. Kalemba, K. Barbusiński, Ochr. Sr. 38, 4, 21-24 (2016)

20. M. Torrijos, P. Sousbie, L. Badey, F. Bosque, Water Sci. Technol. 66, 10, 2237-2242 (2012)

21. J.A.S. López, M.Á.M. Santos, A.F.C. Pérez, A.M. Martín, Bioresour. Technol. 100, 5609-5615 (2009)

22. S. Luste, S. Luostarinen, Bioresour. Technol. 101, 2657-2664 (2010) 